\title{
COMMISSION 9: INSTRUMENTS AND TECHNIQUES (INSTRUMENTS ET TECHNIQUES)
}

\author{
Reports of Meetings, 21, 22 and 27 August 1973
}

President: V. B. Nikonov.

SeCRETARY: H. C. Minnett.

\section{Administrative Meetings, 21 and 27 August 1973}

V. B. Nikonov announced the death of M. G. P. de Barros, I. S. Bowen and Y Väisälä.

The proposed officers of the Commission were approved unanimously as follows: President: A. B. Meinel, Vice-President: J. Ring, Organizing Commitiee: B. Valniček, K. L. Hallam, I. M. Kopylov, W. C. Livingston, N. N. Mihelson, V. B. Nikonov, E. H. Richardson, M. F Walker, G. Wlérick.

The following decisions were adopted.

The Working Group on 'Photoelectric Image Devices' should be organized as follows:

Chairman of Group: M. Walker; Members: Ables, A. Bijaoui, K. Ford, P. V Shcheglov, G. Walker, E. Wampler, G. Wlérick; A Committee of Consultants: W. A. Baum, G. Kron, J. D. McGee, A. Lallemand, V B. Nikonov.

To continue the work of the Working Group on 'Seeing and Site Testing' (Chairman: H. Brück; Members: H. Elsässer, K. O. Kiepenheuer, F. Roddier, J. Rösch, F. Saïssac, P. V. Shcheglov, J.Stock, M. Walker). The scope of its activities will be enlarged to cover all aspects of the problem, including: site testing, theory and practice of seeing and the application of interference methods. It was also resolved that the Executive Committee be informed that a Colloquium on Seeing and Site Testing would be desirable in 1975.

To continue the work of the following Working Groups established at the Brighton meeting of the Commission in 1970.

Working Group on 'Large Telescopes' (Chairman: J. Rösch; Members: I. M. Kopylov, A. B. Meinel, E. H. Richardson, G. M. Sisson, F. L. Whipple).

Working Group on 'Automation and Data Acquisition' (Chairman: L. Robinson; Members: E. Dennison, B. E. Lasker, N. N. Mihelson).

To establish a new Working Group on 'Infra-Red Techniques' (Chairman: J. Ring; Members: F. Low, L. S. Luud, P. Connes, R. V. Karandikar).

To enlarge the scope of the Working Group on 'Photographic Materials' to include all aspects of astronomical photography and to change its name to 'Working Group on Photographic Problems' It was recommended that the Chairman of this Working Group should be W. Miller.

The Joint Working Group of Commissions 9 and 46 on the 'Exchange of Equipment' should be dissolved. The work carried out during the last term has shown that one or two people, acting as a centre of information, would now be adequate to perform its function. This work could be transferred to UNESCO or to a small centre in IAU.

Commission 9 supports the establishment of a new Commission on the 'Protection of Existing and Potential Observatory Sites', in the form of a Commission of the Executive Committee. M. Walker is proposed as the representative of Commission 9.

Commission 9 decided that publication of its Reports would be in the form of:

(a) A short report by the President indicating the main trends in astronomical techniques over the last few years.

(b) A longer report for circulation to all members of Commission 9. 


\section{Scientific Meeting, 27 August 1973}

At the Scientific Meeting of the Commission devoted to the Problem of Large Telescopes $t$ following papers were given:

A. B. Meinel: Introductory Talk.

A. B. Meinel and F. Whipple: Multiple-Mirror Telescope Project.

G. Odgers: Array Telescopes.

J. Rösch: Collecteurs de lumière composites.

\section{Priorities}

A very strong photon hunger is encountered in most cases when making detailed studies galaxies, their nuclei, quasistellar objects, $X$-ray sources, pulsars and many other objects of gre value to the understanding of the fundamental properties of the Universe.

To overcome this photon hunger a new generation of giant telescopes should be created as new types of observational equipment having maximal efficiency in recording single photons shou be developed and put in operation.

These are the problems of highest priority in modern astronomical technique.

Construction of telescopes larger than 6-7 metres in diameter of classical design encounte practically insurmountable difficulties of both a technical and financial nature and new, realis and economic ways of solving this problem are urgently needed.

The work on the new generation of large telescopes and, in particular, on the Multiple Mirr and Array Telescope projects is of the greatest value for the future of astronomy.

At the same time all aspects of the problem of how to reach the high potential resolving pow of large telescopes, restricted in practice by the seeing, should be carefully considered. This shou include not only the search for perfect places for observatories and the correct design of domes at telescopes, but also the use of such special interference methods as speckle interferometry.

A large telescope (diameter 3-4 metres) operating in space should also be created. It could ma possible major breakthroughs in several fundamental areas not attainable with groundbased $i$ struments. This is especially true in the photometry and spectroscopy of faint objects in the ultr violet and infrared and in very high resolution imagery and astrometry.

In spite of remarkable success in developing very fast photographic emulsions in the last $f$ years, photoelectric devices still possess the highest quantum efficiency. A great advantage of mc of these devices is the possibility of applying photon counting methods, permitting digitization the measurements.

New types of photoelectric devices developed recently, such as solid state photodiodes, digico and microchannel, multianode photomultipliers, permit digitization of spectral observations as the observation of surface objects. Further perfection of photoelectric devices and the introductic of this modern technique into current astrophysical research is, as just mentioned, one of the mc pressing problems in the near future.

However, for the studies of finest details of faintest galaxies and galactic nebulae, as well as $f$ spectrographic work of high resolution and the accurate photometric observations of large numbe of very faint stars, electronic cameras are by far the best when compared either with commi photography or with other image tube systems. The electronic cameras with large photocathod developed in France offer new possibilities in galactic research by realizing precise and effecti stellar photometry of the distant parts of the galaxy, especially if modern multicolour photometi systems are used. In this connection, further developments in operating large field electronic camer and special instrumentation for automated measurements of electronographic stellar images a very much needed.

The growing role of infra-red research in modern astronomy requires further work on infra-r astronomical techniques, including further applications of Fourier spectroscopy for high resolutic studies of spectra in the infra-red region. 
One very serious problem must also be noted. It is immediately connected with the effective use of the astronomical techniques. This is the protection of present and future groundbased observing sites from light, air and radio pollution and from atmospheric disturbances produced by jet aviation. At the present time, this problem is becoming critical for some of the largest observatories in the world.

\title{
GROUPE DE TRAVAIL SUR L'EMPLOI EN ASTRONOMIE DES RÉCEPTEURS PHOTOÉLECTRIQUES D'IMAGES
}

\author{
Compte Rendu de la Séance, 22 Août 1973
}

Président: G. Wlérick.

SECRÉTAIRE: F. Roddier.

\section{Résultats scientifiques}

Deux séances ont été consacrées à ces récepteurs le Mercredi 22 Août. Les quatre exposés de synthèse suivants ont été présentés:

H. Mazursky: The Mariner 9 Television system. Instrumentation and results.

G. Wlérick: L'emploi en Astronomie des récepteurs électronographiques.

L. B. Robinson et E. J. Wampler: Image Photon Counting for spectroscopy in Astronomy (présenté par Robinson).

J. L. Lowrance: Astronomical Television Development at Princeton University Observatory. Rickard, de l'ESO, a fait ensuite une courte communication pour montrer comment les récepteurs photoélectriques d'images sont utilisés dans un Observatoire de création récente.

Enfin J. D. McGee a tiré les conclusions de l'ensemble des exposés; il a souligné la nécessité de comparer de façon aussi quantitative que possible les performances des divers récepteurs pour l'étude d'un même objet; il a vivement insisté pour que les développements dans les observatoires se poursuivent au même titre que les développements industriels; il a remarqué que l'électronographie permet d'attaquer des problèmes de plus en plus difficiles et que l'utilisation de récepteurs linéaires en spectroscopie ouvre des possibilités nouvelles pour l'étude des astres faibles. Finalement il a prédit un bel avenir à ces récepteurs.

Tous ces exposés ont été suivis par une nombreuse assistance et largement discutés.

\section{Organisation}

Wlérick a indiqué qu'il a dirigé le noyau administratif du groupe pendant six ans (il avait succédé à Baum et $\mathrm{McGee}$ ) et il a fait part de son souhait d'être remplacé dans cette tâche. L'organisation suivante à été adoptée:

Le 'Comité des Sages' est maintenu; ses membres sont: Baum, Kron, Lallemand, McGee, Nikonov.

Le Comité administratif comprend:

Président: M. Walker

Membres: Ables, Bijaoui, Carruthers, Ford, P. V. Shcheglov, G. Walker, Wampler, Wlérick.

C'est un devoir agréable de noter pour terminer, que la Commission 9 unanime a regretté l'absence de A. Lallemand et exprimé le souhait qu'il continue à la faire bénéficier de son concours. 